\title{
Migration Abroad for Temporary Employment and Its Effects on the Country of Origin
}

\author{
Chung H. Lee*
}

One of the significant developments in the world economy in recent years is international migration for temporary employment to the oil producing countries of the Middle East and North Africa. In 1975, for instance, there were nearly 1.7 million foreign workers in the eight major oil-producing countries of the region, and they constituted $27 \%$ of the labor force of the host countries. ${ }^{1}$ Most of these workers came from other Arab countries and the Indian subcontinent, but more recently Korea and the Philippines have become major suppliers of foreign workers in the region. ${ }^{2}$

One of the distinguishing characteristics of international migration to the Middle East and North Africa from countries such as Korea and the Philippines is that it is migration for temporary employment and not for permanent settlement. Migrant workers return to their countries of origin in a year or two, and their earnings are regularly remitted to their families. Because of the temporary nature of migration and the regular remittance of earnings there is no ambiguity at all, unlike in the case of permanent migration, as to the identity of the country to which migrants belong in economic analysis of their migration.

Another characteristic of the migration is that most of migrants are not highly trained professionals. Some of them are skilled workers and engineers, but most of them are common laborers and construction workers. Their migration does not, therefore, bring about partitioning of the domestic labor market into internationally mobile and immobile segments and consequent distortionary problems.

In countries with a Lewisian surplus of labor international migration for temporary employment increases national income without decreasing domestic output. However, in

* Professor of Economics, University of Hawaii at Manoa and concurrently Research Associate at Resource Systems Institute, East-West Center.

He wishes to thank Max Corden, Sumner La Croix, Harvey Lapan, Tony Yeh and an anonymous referee for useful comments and suggestions on an earlier version of the paper.

${ }^{1}$ See Serageldin and Socknat (1980) and references therein.

${ }^{2}$ In 19;7 there were 45,725 Koreans employed in construction projects in the region. This number increased to 171,170 in 1982 . See Lee (1984). 
countries such as Korea, which has passed the Lewisian turning point, it has general equilibrium effects, and "Dutch disease" or "booming sector" economics provides a ready theoretical framework for their analysis. ${ }^{3}$

The Dutch disease, as originally stated, refers to the adverse effect on traditional manufacturing industries of an oil or gas field discovery. The discovery leads to a higher real exchange rate (the price of nontradeables in tradeables) than otherwise, and consequently resources move out of the traditional manufacturing sector (or the "lagging" sector) with its exports declining. The Dutch disease or booming sector economics has, however, a wider range of applications than the case of an oil or gas field discovery. As noted by Corden (1982), it is applicable to wherever there is a sectoral export boom accompanied with adverse effects on other tradeables sectors. In this paper it will be shown that booming sector economics is also applicable to the case where a boom occurs outside the country, providing that the boom pulls some of the resources from domestic employment.

In addition to the Dutch disease effect the country of origin may experience a deterioration in its international terms of trade due to migration. It is readily conceivable then that with a large enough deterioration in the terms of trade the country may become worse off due to migration than otherwise. ${ }^{4}$ Even if the terms of trade are independent of migration, it is possible for the country to become worse off, as will be shown in this paper, due to migration.

The purpose of the present paper is twofold. The first is to present a positive analysis of the effects of temporary migration on the economy of the country of origin. The second is to present a welfare analysis of migration for the country which is assumed to be a small open economy.

In Section I, utilizing the theoretical framework of Corden and Neary (1982) we analyze the case where labor is less than perfectly mobile internationally although it is perfectly mobile within the country. In this section overseas earnings are sent back home and spent in the first period and migrants return home in the second period. In Section II we consider the case where overseas earnings are brought back in the second period when migrants return home. In Section III we present a model of international migration for temporary employment and demonstrate a case where migration is welfare-improving for the entire country. The model follows closely a pioneering work by Rivera-Batiz (1982) where nontraded goods are introduced in welfare-analysis of emigration. Our model,

\footnotetext{
${ }^{3}$ For a comprehensive review of the literature, see Corden (1982).

${ }^{4}$ In a model of permanent migration, Kenen (1971) demonstrates the possibility of the remaining nonmigrants becoming worse off due to a terms of trade deterioration.
} 
however, differs from his in that it deals with temporary, not permanent, migration. In Section IV we employ the model to demonstrate the possibility of "immiserizing migration." Section V summarizes and concludes the paper.

\section{I}

The country of origin of international migration for temporary employment is a small open economy consisting of tradeables and nontradeables sectors. Migrants are paid in a foreign currency at a given wage rate higher than the domestic wage rate. Since the prices of tradeables are given in the rest of the world, it may be assumed that migrants are paid with a fixed quantity of tradeables.

The country of origin is assumed to have the Ricardo-Viner model of production where labor is mobile between the sectors but all other factors are sector-specific. Labor has, therefore, diminishing returns in each use. Figure 1 depicts this model of production with a given initial endowment of labor, $0_{T} 0_{N}$, which prior to migration is distributed between the tradeables and nontradeables sectors. The vertical axes in Figure 1 measure

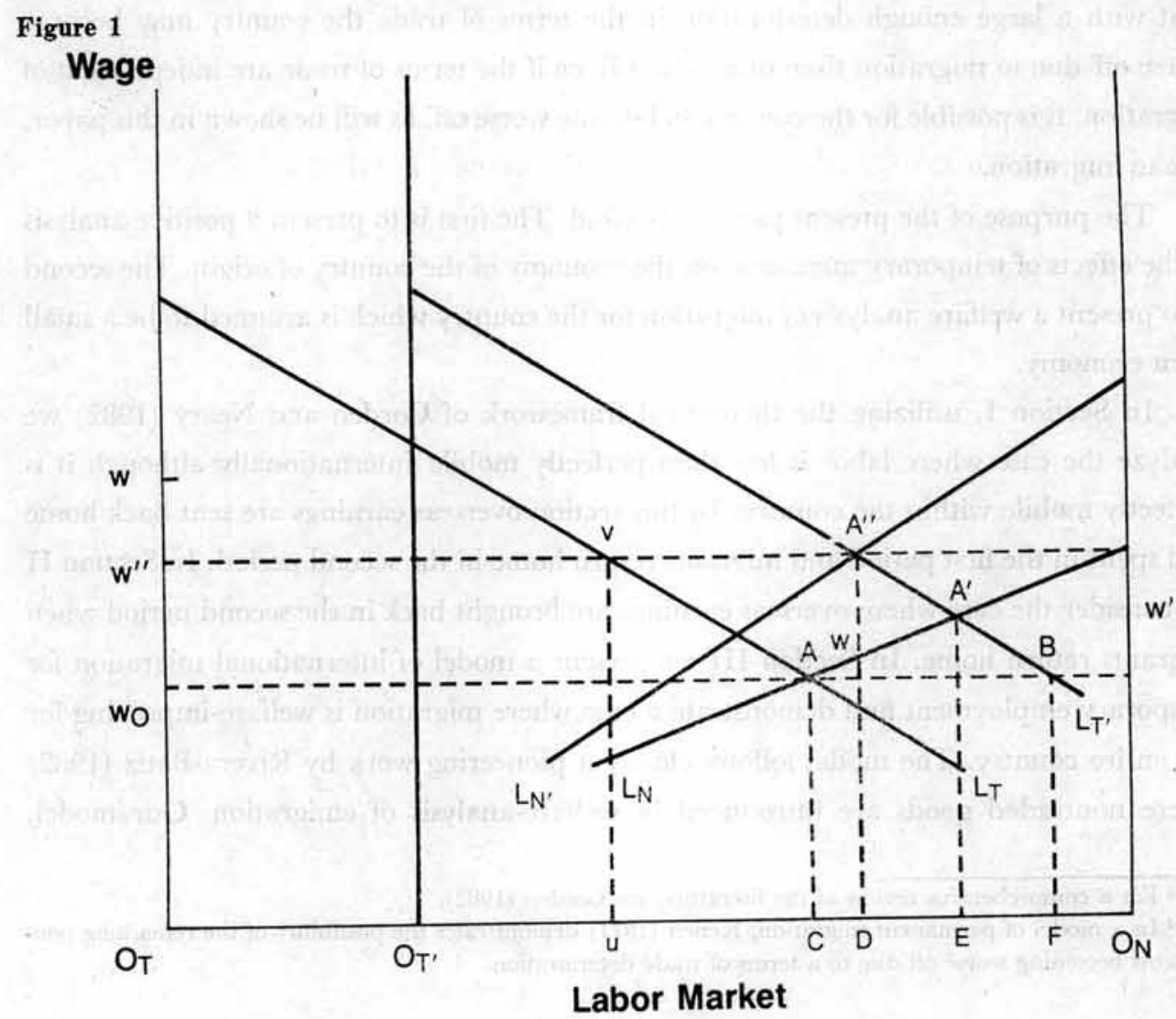


the wage rate in terms of tradeables, and $L_{T}$ and $L_{N}$ are the labor demand curves in the tradeables and nontradeables sectors, respectively. $L_{N}$ is drawn at the given initial real exchange rate, which is assumed to be one with no loss of generality. The demand curves slope downward indicating the diminishing marginal product of labor. Initial equilibrium is reached at point $\mathrm{A}$ where the two demand curves intersect. Equilibrium wage rate is $w_{O}$, and $0_{T} C$ of the labor force is employed in the tradeables sector and $0_{N} C$ in the nontradeables sector.

Now an overseas market for domestic labor is discovered where a higher wage rate than $w_{O}$ is offered. Labor migrates overseas but because of barriers to movement only $0_{T} 0_{T}$, migrates overseas. By assumption this quantity is less than the quantity that would equalize the domestic and overseas wage rate.

The effect of migration at the initial real exchange rate is to move the equilibrium point from $\mathrm{A}$ to $\mathrm{A}^{\prime}$, raising the domestic wage rate from $w_{0}$ to $w^{\prime}$. Employment in the tradeables sector decreases from $0_{T} C$ to $0_{T}, E$, a contraction by $E F$, and employment in the nontradeables sector decreases from $0_{N} C$ to $0_{N} E$, a contraction by $C E$. In other words the resource movement effect is to contract both sectors, and there is de-industrialization if the tradeables sector is also an industrialized sector.

Migration brings about a decrease in GDP. At the initial real exchange rate the output of tradeables decreases by $E A^{\prime} B F$ and the output of nontradeables decreases by $C A A^{\prime} E$, all measured in terms of tradeables. The decrease in GDP at the initial real exchange rate is the sum of these two, $C A A^{\prime} B F$.

Migrants are paid at $\bar{w}$ and thus remit $\bar{w}\left(0_{T} 0_{T^{\prime}}\right)$ of tradeables. ${ }^{5}$ It is easily seen from Figure 1 that this area is larger than $C A A^{\prime} B F$. That is, the post-migration GNP, GDP plus remittances, is greater than the initial GNP and of course is greater than the postmigration GDP. In other words migration has led to a contraction in output in both sectors but increased GNP at the initial real exchange rate. ${ }^{6}$ If tradeables and nontradeables are normal goods, there is now excess demand in each sector at the initial real exchange rate. The excess demand for tradeables will be met with net imports, but there being no imports

${ }^{5}$ Here, for the sake of simplicity we assume that all wages are remitted. Of course, the fact is that some are consumed abroad by migrants, but since the objective of temporary migration is to remit as much as possible there is no point in treating the proportion of wages remitted as a decision variable of an individual migrant. In Section II we deal with the case where all wages are brought back when migrants return home, but the timing of remittance.

${ }^{6} \mathrm{It}$ may appear in Figure 1 that if the overseas wage rate is slightly higher than $w_{0}$ the increase in wage income can be less than the loss in income to specific factors, $A A$ ' $B$. If so, the post-migration GNP is less than the initial GNP. This, however, will not occur since in that case the post-migration domestic wage rate is higher than the overseas wage rate and there will be no migration. As long as the overseas wage rate is higher than the domestic wage rate, the post-migration GNP at the initial real exchange rate is greater than the initial GNP. 


\section{Figure 2}

\section{Tradeables}

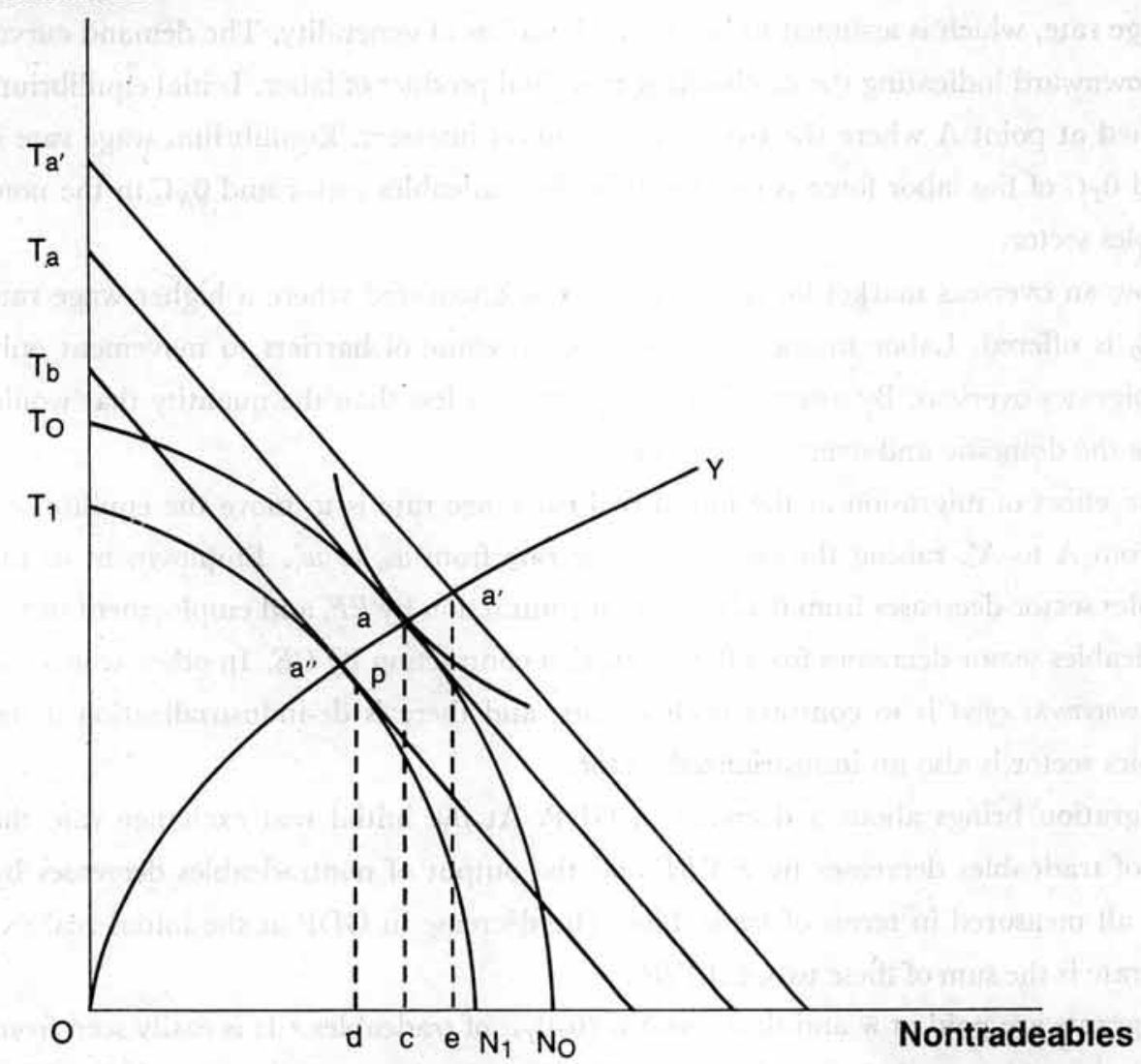

to satisfy the excess demand in the nontradeables sector the real exchange rate will appreciate. ${ }^{7}$ That is, the spending effect of remittances is to bring about real appreciation with its consequent effects on resource allocation.

What happens to the real exchange rate when there is excess demand for nontradeables can be readily demonstrated in the Salter diagram shown in Figure 2. There the vertical axis measures tradeables and the horizontal axis measures nontradeables. $\tau_{0} \mathcal{N}_{0}$ is the initial production possibility curve and point a denotes the initial equilibrium where the production possibility curve is tangent to a social indifference curve. ${ }^{8} O T_{a}$

${ }^{7}$ In the real world with money real appreciation may occur either through a nominal appreciation of the home currency or through an increase in the price of nontradeables as remittances increase the money supply.

8 This production possibility curve is a short-run transformation curve of an economy with sector specific factors. It lies inside the long-run production possibility curve except at the point where the distribution of specific factors is the same as their long-run distribution. For a further discussion of the relationship between short-run and long-run transformation curves, see Mayer (1974). 
measures the initial GNP in terms of tradeables and $0 c$ measures the quantity of nontradeables produced and consumed before the migration.

Migration shifts the production possibility curve to $T_{1} \mathcal{N}_{1}$ and GDP decreases at the initial real exchange rate to $0 T_{b}$. The post-migration GNP is, however, greater than the initial GNP because of the remittances which are shown here as $\left(T_{a^{\prime}}-T_{b}\right)$. With curve $0 Y$ being the income expansion path at the initial real exchange rate the demand for nontradeables is $0 e$, which is greater than their supply, Od. The excess demand for nontradeables brings about a real appreciation. ${ }^{9}$

\section{Figure 3}

\section{Tradeables}

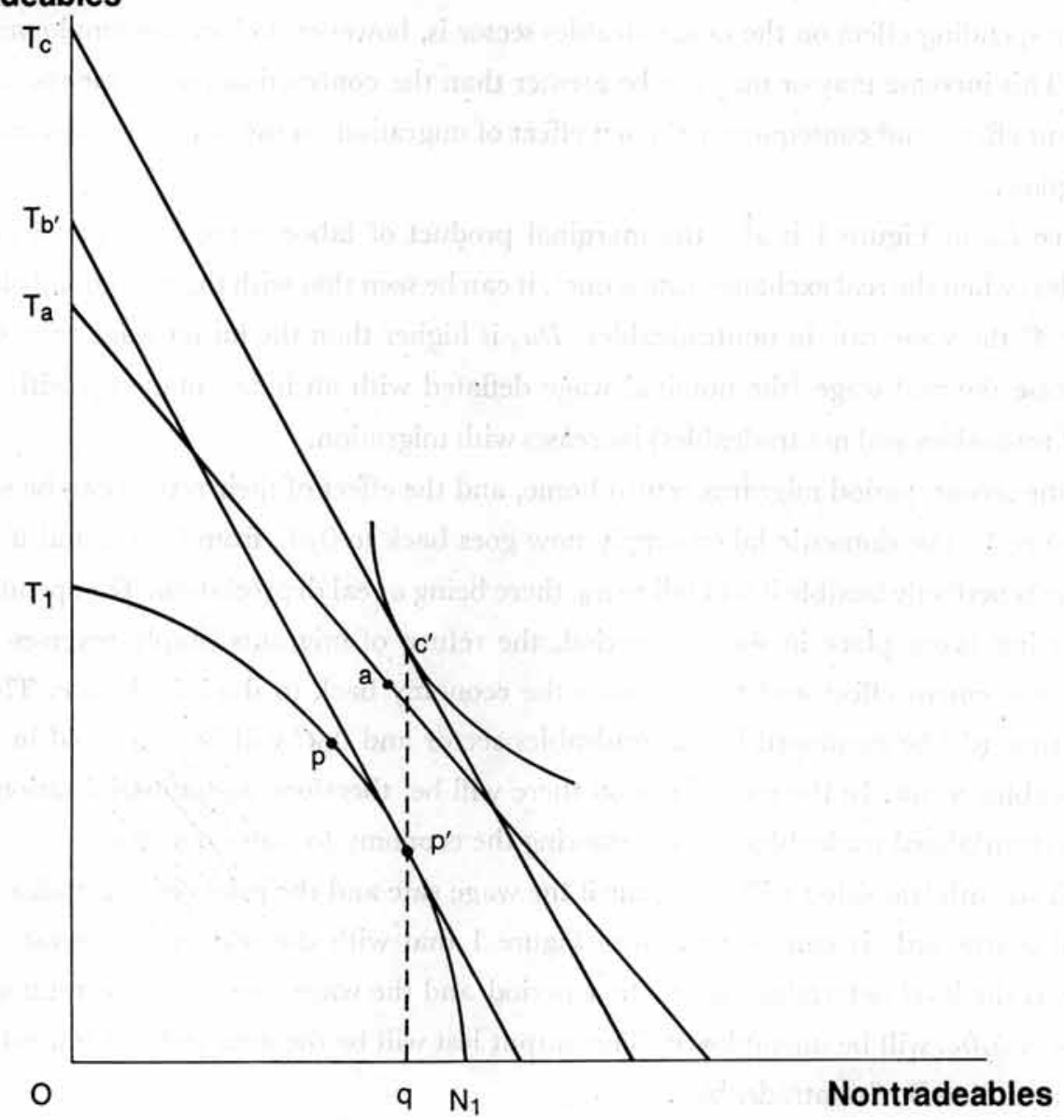

${ }^{9}$ The effect of international migration for temporary employment on the country of origin can be decomposed into the effects of two transfers. Migration is a transfer of real resources whereas receiving remittances is a transfer of purchasing power. The country of origin is, therefore, a transfer of real resources and at the same time a transferee of purchasing power. Clearly, then, it is possible to deal with the issues raised in this paper in the theoretical framework of the transfer problem. 
The new equilibrium is described in Figure 3 where point $p^{\prime}$ is the production point and point $c^{\prime}$ is the consumption point. Now the supply of and the demand for nontradeables are equal at $O q$, and the excess demand for tradeables, $p^{\prime} c^{\prime}$, is met with net imports. With no other entries in the balance of payments this deficit on merchandise account is equal to the wages remitted by migrants.

The effect of a real appreciation on the labor market is seen in Figure 1. With real appreciation tie demand for labor curve in the nontradeables sector shifts up equiproportionately from $L_{N}$ to $L_{N^{\prime}}$. The new equilibrium point is $A^{\prime \prime}$ and the equilibrium wage rate is $w^{\prime \prime}$. Thus, the spending of remittances further decreases employment in the tradeables sector from $0_{T}, E$ to $0_{T}, D$. The total contraction of the tradeables sector is $E F$ plus $D E$. The spending effect on the nontradeables sector is, however, to increase employment by $D E$. This increase may or may not be greater than the contraction due to the resource movement effect, and consequently the net effect of migration on the nontradeables sector is ambiguous.

Since $L_{N}$ in Figure 1 is also the marginal product of labor curve in terms of nontradeables (when the real exchange rate is one), it can be seen that with the new equilibrium at point $A^{\prime \prime}$ the wage rate in nontradeables, $D w$, is higher than the initial wage rate, $C A$. In this case the real wage (the nominal wage deflated with an index made up with the prices of tradeables and nontradeables) increases with migration.

In the second period migrants return home, and the effect of their return can be seen from Figure 1. The domestic labor supply now goes back to $0_{T} 0_{N}$ from $0_{T}, 0_{N}$, and if the wage rate is perfectly flexible it will fall to $w_{0}$, there being a real depreciation. The spending effect having taken place in the first period, the return of migrants simply reverses the resource movement effect and thus restores the economy back to the initial state. Thus, $0_{T} C$ of labor will be employed in the tradeables sector and $0_{N} C$ will be employed in the nontradeables sector. In the second period there will be, therefore, re-industrialization of the de-industrialized tradeables sector, restoring the economy to status quo ante.

This smooth transition will not occur if the wage rate and the prices of nontradeables are rigid downward. It can be seen from Figure 1 that with the real exchange rate remaining at the level determined in the first period and the wage rate at $w^{\prime \prime}$ the returning migrants of $0_{T} 0_{T}$, will be unemployed. The output lost will be the area $u v A C$ of tradeables and the area $C A w D$ of nontradeables.

In the preceding section we have seen that migration brings about de-industrialization 
of the tradeables sector but has an ambiguous effect on the nontradeables sector. These are consequences of allowing the resource movement and the spending effects to take place in the same period. Since, however, they can be temporally separated, it is of interest to know how the two sectors will be affected if the spending effect is allowed to take place later than the resource movement effect. This can be done either by allowing migrants to bring their foreign exchange earnings only when they return home in the second period or, if the earnings are remitted in the first period, by sterilizing the monetary effect of the remittances until migrants return home in the second period. This may be accomplished by having dollar earnings exchanged for bonds which are then redeemed in the second period.

In the first period then only the resource movement effect will take place as total expenditures are maintained equal to GDP. At the initial real exchange rate both sectors contract due to migration, but without the spending effect there may be either excess demand or excess supply in the nontradeables sector. The case of excess supply can be seen from Figure 2 where $T_{1} N_{1}$ is the post-migration production possibility curve, $p$ the production point and $a^{\prime \prime}$ the consumption point at the initial real exchange rate. There is now

Figure 4

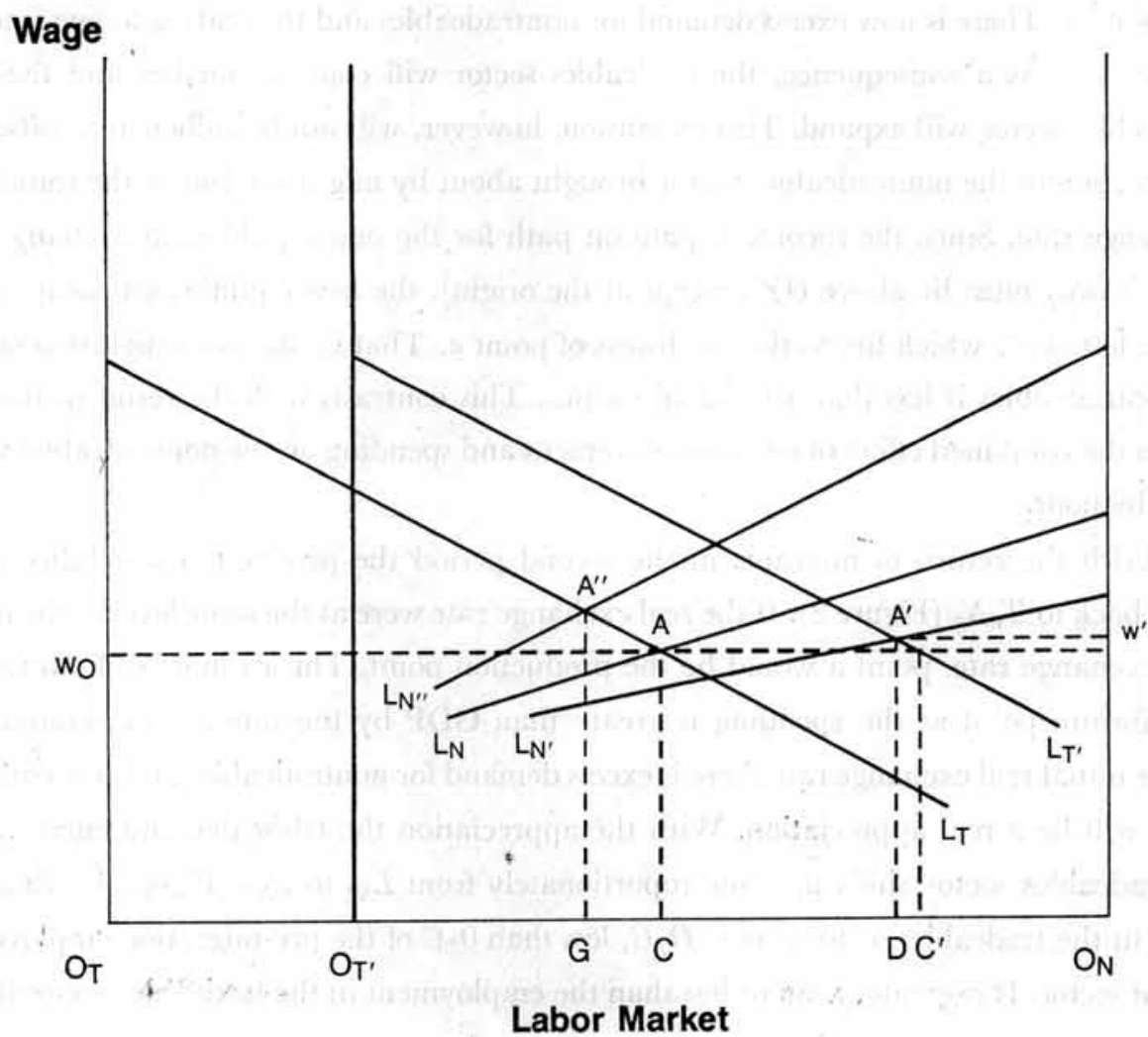


excess supply of nontradeables and the real exchange rate will therefore depreciate. With the depreciation the labor demand curve in the nontradeables sector shifts down equiproportionately from $L_{N}$ to $L_{N^{\prime}}$ (Figure 4). The equilibrium wage rate is $w^{\prime}$ and employment in the tradeables sector is $0_{T}, D$. In this case de-industrialization is less than the case where the spending effect takes place in the first period.

Is it possible for real depreciation to be large enough to lower the wage rate below $w_{0}$ and thus to increase employment in the tradeables sector? That this is not possible can be seen from Figure 2. The income expansion path (not drawn) for the new equilibrium exchange rate must lie below $0 Y$ (except at the origin) but must pass through a point on $T_{1} \mathcal{N}_{1}$ lying to the left of point $p$. The new equilibrium point on $T_{1} \mathcal{N}_{1}$ must therefore lie to the southwest of point $a$. That is, migration with the spending of remittances postponed to a later period reduces the output of tradeables and employment in that sector. The new equilibrium wage rate must be, therefore, higher than $w_{0}$. Since $L_{N^{\prime}}$ must lie below $L_{N}$ with a real depreciation, it is seen that the nontradeables sector contracts due to the real depreciation as well as due to the resource movement effect.

The production possibility curve may shift in such a manner that the new production point at the initial real exchange rate (not shown in Figure 2) lies to the left of point $a^{\prime \prime}$ in Figure 2. There is now excess demand for nontradeables and the real exchange rate will appreciate. As a consequence, the tradeables sector will contract further and the nontradeables sector will expand. This expansion, however, will not be sufficient to offset the contraction of the nontradeables sector brought about by migration but at the initial real exchange rate. Since the income expansion path for the new equilibrium exchange rate (not drawn) must lie above $O Y$ (except at the origin), the new equilibrium point will be to the left of $a^{\prime \prime}$, which lies to the southwest of point $a$. That is, the post-migration output of nontradeables is less than the initial output. This contrasts with the result in the case where the combined effect of resource movement and spending on the nontradeables sector is ambiguous.

With the return of migrants in the second period the production possibility curve shifts back to $T_{0} \mathcal{N}_{0}$ (Figure 2). If the real exchange rate were at the same level as the initial real exchange rate, point a would be the production point. This cannot be, however. an equilibrium point as the spending is greatr than GDP by the amount of remittances. At the initial real exchange rate there is excess demand for nontradeables and consequently there will be a real appreciation. With the appreciation the labor demand curve in the nontradeables sector shifts up equiproportionately from $L_{N^{\prime}}$ to $L_{N^{\prime \prime}}$ (Figure 4). Employment in the tradeables sector is now $O_{T} G$, less than $0_{T} C$ of the pre-migration employment in that sector. It is greater than or less than the employment in the tradeables sector in the 
first period, depending on the extent of real appreciation.

With the spending of remittances postponed to the second period, employment in the nontradeables sector decreases in the first period. But, when migrants return home in the second period employment in that sector increases, and because of the spending effect it expands beyond the initial level of employment $\left(0_{N} G\right.$ v. $0_{N} C$ in Figure 4$)$.

\section{III}

In order to carry out a welfare analysis for the country of origin, migrants, and nonmigrants we now divide the country's population between (potential) migrants and nonmigrants. Capital is now mobile internally between sectors and is owned entirely by nonmigrants. Furthermore, it is assumed that everyone in the country has identical and homothetic tastes and that within each group everyone has an identical factor endowment. That is, every (potential) migrant has an equal amount of labor and every nonmigrant has an equal amount of labor and an equal amount of capital. This assumption allows us to use community indifference curves of each group for welfare comparison and those of the country for potential welfare comparison. That is, for each group of migrants and nonmigrants a movement from one community indifference curve to a higher one indicates a welfare improvement for everyone in the group. For the country as a whole, however, the same movement indicates an improvement in potential welfare in the sense that income could be redistributed to make everyone in the country better off than in the initial equilibrium. ${ }^{10}$ Following Krause (1976) we also assume that migrants work abroad but spend their income at home. In this section we assume with no loss of generality that the nontradeables sector is labor-intensive relative to the tradeables sector. It is also assumed that each sector has a linear homogeneous production function.

The Salter diagram in Figure 5 presents the model described above. $P_{0} P_{0}^{\prime}$ is its premigration production-possibilities frontier and $U_{0}$ is a community indifference curfe for the entire population. Point a is the pre-migration equilibrium point, the slope of $P_{0} P_{0}^{\prime}$ at point a is the price of nontradeables, and $O Y_{0}$ is the income-consumption curve at that price. With no remittances from abroad the production-possibilities frontier is also the country's consumption-possibilities frontier.

Following Bhagwati and Brecher (1980 and 1981) we may draw the productionpossibilities frontier for nonmigrants. Since potential migrants own only labor and since the nontradeables sector is labor-intensive relative to the tradeables sector, nonmigrants'

${ }^{10}$ See Tower (1979) for a simple but clear discussion of sufficient conditions for the use of community indifference curves. 


\section{Figure 5}

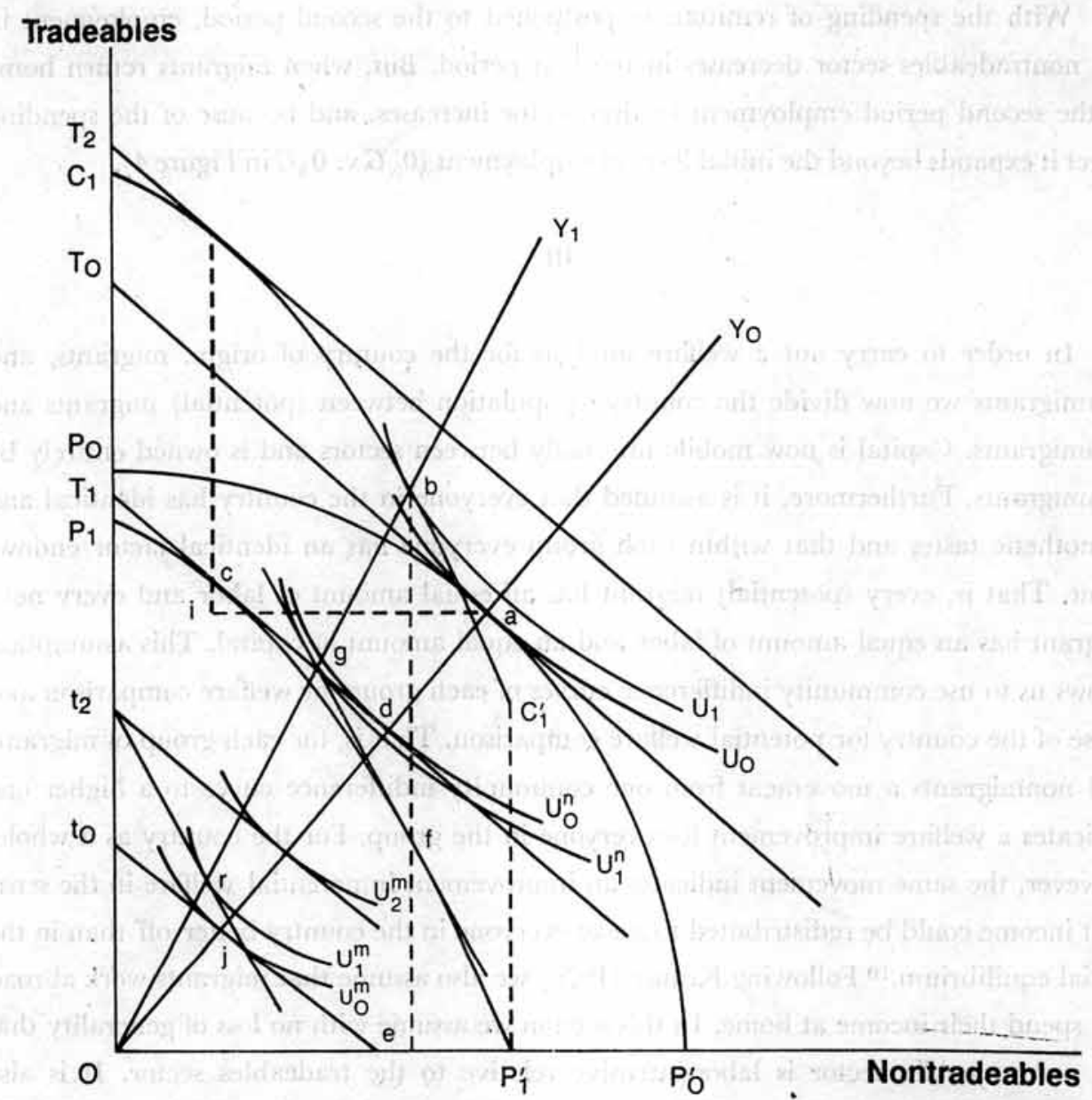

production-possibilities frontier is $P_{1} P_{1}^{\prime}$ in accordance with the Rybzcynski theorem. Their production point is at point $c$ and their income is $T_{1}$ in terms of tradeables. Line $\tau_{1} c$ is the budget line for nonmigrants, their consumption point is poind $d$, and their welfare level is represented by the community indifference curve $U_{0}^{n}$. It is clear that the presence of potential migrants at home increases the country's output of nontradeables by $\bar{i}$ but decreases its output of tradeables by $i c$.

The income of potential migrants is $\left(T_{0}-T_{1}\right)$ in terms of tradeables. Their budget line is $t_{0} j$, shown at the lower left-hand corner of the diagram, where $0 t_{0}$ is equal to $\left(T_{0}-\right.$ $T_{1}$ ); their consumption point is point $j$ on the budget line; and their welfare level is represented by the community indifference curve $U_{0}^{m}$.

Now, international migration for temporary employment takes place, and the country's production-possibilities frontier in fact shifts from $P_{0} P_{0}^{\prime}$ to $P_{1} P_{1}^{\prime}$. That is, with migra- 
tion nonmigrants' production-possibilities frontier becomes the country's productionpossibilities frontier. GNP increases, however, by the amount of remittances, $\left(T_{2}-T_{1}\right)$, which is greater than $\left(T_{0}-T_{1}\right)$, the income which migrants would have earned if they had stayed at home.

Because of remittances the post-migration consumption-possibilities frontier, $C_{1} C_{1}^{\prime}$, is not identical with the post-migration production-possibilities frontier. $C_{1} C_{1}^{\prime}$ is drawn by sliding $\left(T_{2}-T_{1}\right)$ continuously along $P_{1} P_{1}^{\prime}$, and consequently points on $C_{1} C_{1}^{\prime}$ and $P_{1} P_{1}^{\prime}$ with the same horizontal coordinate have the same slope. It is clear from Figure 5 that the post-migration consumption-possibilities frontier does not dominate the pre-migration consumption-possibilities frontier in the entire range.

Point $b$ is the post-migration equilibrium point: $\overline{O_{e}}$ of nontradeables is produced and consumed; $\overline{e f}$ of tradeables is produced but $\overline{e b}$ of the same is consumed. The difference, $\overline{f b}$, is net imports of tradeables and is equal to the remittances. The production point for nonmigrants is point $f$, their post-migration: budget line is line $f g$, and their consumption point is point $g$. Figure 5 shows a case where migration makes nonmigrants worse off than otherwise.

Migrants' income is $t_{2}\left(=T_{2}-T_{1}\right)$ and their budget line is line $t_{2} r$, which is parallel to line $f g$. Their welfare level is $U_{1}^{m}$ which is higher than $U_{0}^{n}$.

Migrants are, therefore, better off with migration than otherwise, although they are not so well off as they would be at the initial price of nontradeables. The effect of their migration and the spending of remittances is, however, to increase the price of nontradeables, and since their overseas income is entirely in terms of tradeables the price increase reduces their real wage. The welfare level is $U_{1}^{m}$ instead of $U_{2}^{m}$ but it is still higher than $U_{0}^{m}$.

The case demonstrated in Figure 5 is the same in conclusion as that of Rivera-Batiz (1983) where migrants are better off but nonmigrants are worse off due to migration. We can go, however, one step further in our conclusion: migration in the case shown in Figure 5 makes the country potentially better off than otherwise.

\section{IV}

In this section we demonstrate conditions under which migration can be welfareworsening for the entire country. In the first case tradeables are relatively labor-intensive and tastes are biased in favor of tradeables. In the second case non-tradeables are relatively labor-intensive and tastes are biased in favor of non-tradeables. We should add that for migration to be immiserizing it is not necessary to assume that tastes are biased in favor of labor-intensive commodities. The assumption only make it more likely. 


\section{Figure 6}

\section{Tradeables}

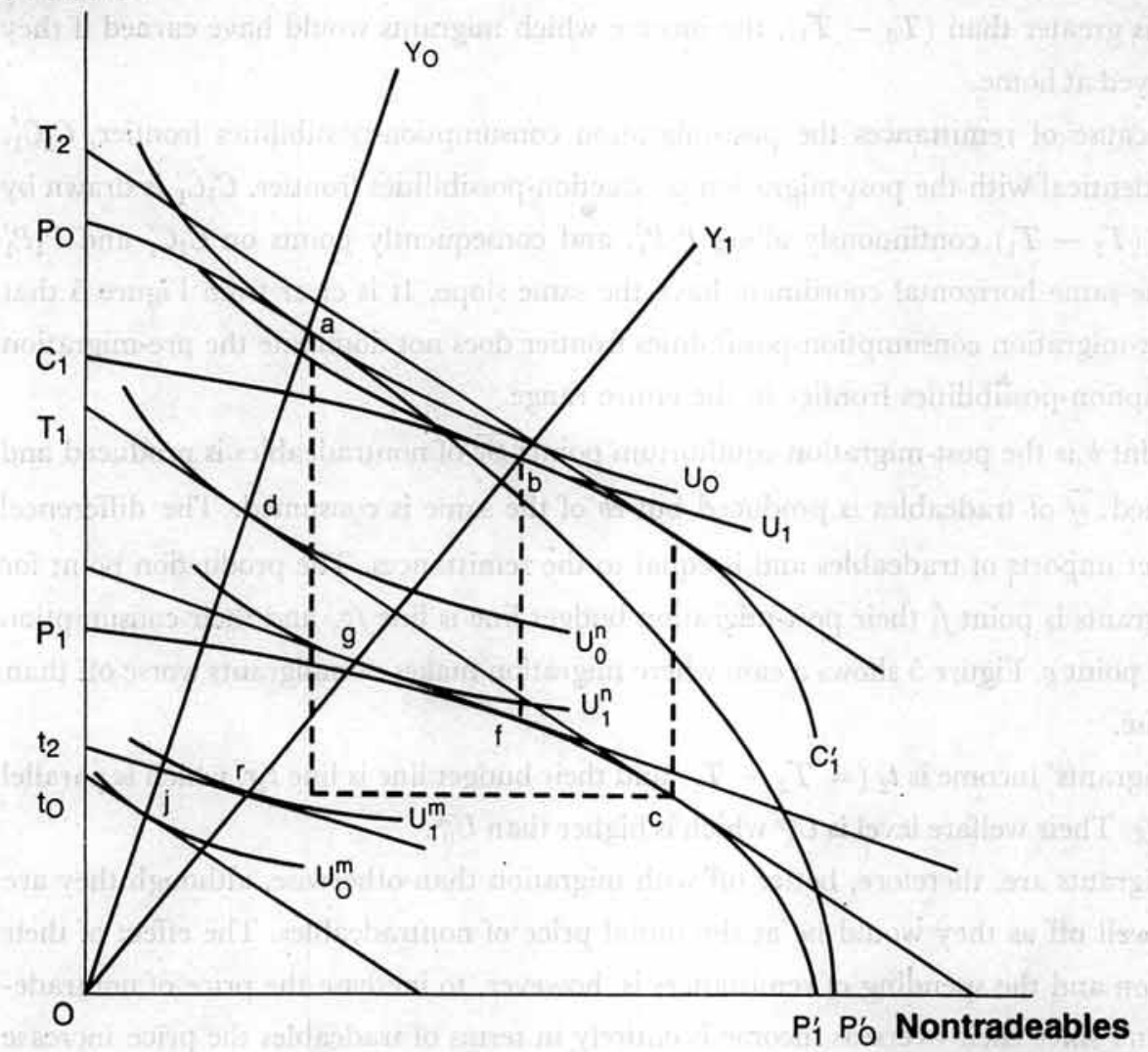

In Figure 6 tradeables are relatively labor-intensive and tastes are biased in favor of tradeables. The pre-migration equilibrium is at point a and the country's welfare level is $U_{0}$. Again, by the reasoning of Bhagwati and Brecher and that of Rybczynski $P_{1} P_{1}^{\prime}$ is the production-possibilities frontier of nonmigrants, and their welfare level is $U_{0}^{n}$.

Now migration takes place and migrants earn $t_{2}$ of tradeables from their overseas employment. Hence, the post-migration consumption-possibilities frontier for the country is $C_{1} C_{1}^{\prime}$ and the post-migration equilibrium is at point $b$. The effect of migration is to lower the price of nontradeables. The post-migration production is at point $f$, and nonmigrants' welfare level is $U_{1}^{n}$, which is lower than $U_{0}^{n}$.

Migrants send home $t_{2}$ of tradeables which is greater than their pre-migration income of $t_{0}$. Their welfare level is now $U_{1}^{m}$, which is higher than $U_{0}^{m}$. Since potential migrants will be better off with migration, it will take place. It will, however, result in a decrease in the country's potential welfare from $U_{0}$ to $U_{1}$.

In Figure 7 nontradeables are labor-intensive and tastes are biased in favor of non- 


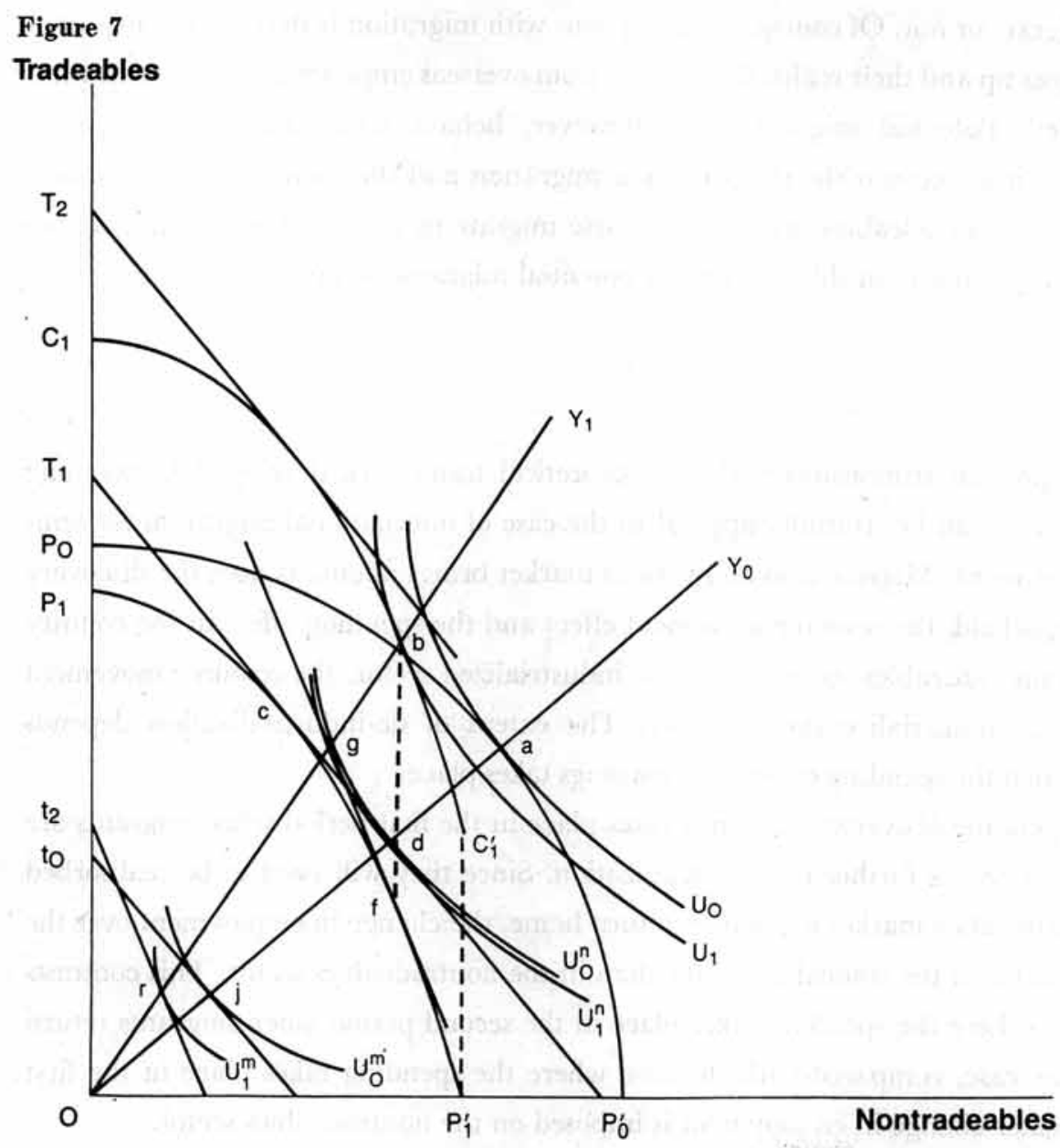

tradeables. The initial equilibrium is at point a and the country's welfare level is $U_{0}$. Nonmigrants' income is $T_{1}$ in terms of tradeables and their welfare level is $U_{0}^{n}$. Potential migrants' income is $t_{0}$ in terms of tradeables, and their welfare level is $U_{0}^{m}$.

With migration migrants earn $t_{2}$ of tradeables from their overseas employment. Now the consumption-possibilities frontier is $C_{1} C_{1}^{\prime}$ and the post-migration equilibrium is at point $b$. The post-migration production is at point $f$, and their welfare level equals $U_{1}^{n}$. As can be seen in Figure 7, their welfare level has decreased due to migration.

Instead of producing commodities at home migrants now send home $t_{2}$ of tradeables which is greater than their pre-migration income. But because of an increase in the price of nontradeables their welfare level in fact goes down from $U_{0}^{m}$ to $U_{1}^{m}$.

What we have demonstrated here is a case where both migrants and nonmigrants become worse off with migration. This is a possibility, however, only if potential migrants consider only pre-migration wage rates from domestic and overseas employment in de- 
ciding to migrate or not. Of course, what happens with migration is that the price of nontradeables goes up and their realized real wage from overseas employment is less than what they expected. Potential migrants who, however, behave with rational expectations and thus take into account the effect of their migration and the spending of remittances on the price of nontradeables, will not of course migrate in the first place. Immiserizing migration is a possibility in this case only if potential migrants behave irrationally.

\section{V}

This paper has demonstrated that a theoretical framework developed in booming sector economics can be fruitfully applied to the case of international migration for temporary employment. Migration to an overseas market brings about, as does the discovery of an oil or gas field, the resource movement effect and the spending effect in the country of origin. If the tradeables sector is also the industrialized sector, the resource movement effect is to de-industrialize the economy. The extent of de-industrialization depends further on when the spending of overseas earnings takes place.

If the spending of overseas earnings takes place in the first period when migrants are still abrcad, it causes further de-industrialization. Since they will need to be reabsorbed in the domestic labor market when they return home, the change in employment over the periods is greater in the tradeables sector than in the nontradeables sector. This contrasts with the case where the spending takes place in the second period when migrants return home. In this case, compared with the case where the spending takes place in the first period, a greater change in employment is imposed on the nontradeables sector.

Obviously in our simple model with costless employment adjustment there is no reason for the government to regulate when the spending should take place on the grounds of its effect on employment. If, however, adjustment costs are positive and different between the two sectors, it is not a matter of indifference to the government when the spending of overseas earnings takes place.

Evidence in support of the de-industrialization effect of migration may be found in Korea's export performance in the second half of the 1970s. It deteriorated because of rapid increase in unit-labor cost and the appreciation in the real exchange rate. During this period there was significant migration to the Middle East on construction projects, and what did happen is exactly in accordance with the prediction of our model in Section I. Hong Kong, Singapore, and Taiwan, which together with Korea comprise the newly industrializing countries in Asia and which did not send workers abroad, did not experience the same deterioration in export performance. 
This paper has also demonstrated that immiserizing migration can occur even though the country's international terms of trade are given and there are no price distortions. This can happen because, instead of producing commodities at home migrants now exchange their labor services for tradeables with the rest of the world and they then trade tradeables for nontradeables with nonmigrants. It is the resulting change in the price of nontradeables which can deteriorate the country's potential welfare as well as the welfare of nonmigrants.

The situation analyzed in this paper is similar to a situation where a country changes its trade partner. Suppose that initially country A has free trade only with country B. Now, for some reason country A severs its relationship with country B and engages in free trade with country C. Since country A's comparative advantage vis-a-vis country C will not necessarily be the same as that vis-a-vis country $\mathrm{B}$, its trade pattern may change as a result of the change in trade parrnership. This change can be either welfare-improving or welfare-worsening for country A.

Of course, the question we need to answer is why country A would voluntarily change its trade partner and become worse off. In the case of migration the decision to migrate is made by migrants independently of its welfare effect on nonmigrants. If migrants become better off with migration, then it will take place even though nonmigrants become worse off and the country's potential welfare decreases as a result.

\section{References}

Bhagwati, Jagdish N. and Richard Brecher "National welfare in an open economy in the presence of foreign-owned factors of production," Journal of International Economics, 1980, 10, pp. 103-115.

Brecher, Richard A. and Jagdish Bhagwati "Foreign ownership and the theory of trade and welfare," Journal of Political Economy, 1981, 89, pp. 455-474.

Corden, W. M. "Booming sector and Dutch disease economics: a survey," Working Paper No. 079, Australian National University, 1982.

and Neary, J. P. "Booming sector and de-industrialization in a small open economy," Economic Journal, 1982, vol. 92, pp. 825-48.

Kenen, Peter B. "Migration, the terms of trade, and economic welfare in the source country', in: Jagdish N. Bhagwati et. al., eds. Trade, balance of payments and growth, Amsterdam, North-Holland, 1971.

Krause, Melvyn B. "The economics of the 'guest worker' problem: a new Heckscher-Ohlin approach," Scandinavian Journal of Economics, 1976, 78, pp. 470-476.

Lee, Chung H. "Government promotion measures for construction services exports to the Middle East," East-West Center mimeo, 1984.

Mayer, W. "Short-run and long-run equilibrium for a small open economy," Journal of Political Economy, 1974, 82, pp. 955-67.

Rivera-Batiz, Francisco L. "International migration, non-traded goods and economic welfare in the source country," Journal of Development Economics, 1982, 11, pp. 81-90. 
Rivera-Batiz, Francisco L. "The economics of the 'to and fro' migrant: some welfare-theoretical considerations," Scandinavian Journal of Economics, 1983, 85, pp. 403-413

Serageldin, I. and Socknat, J. "Migration and manpower needs in the Middle East and North Africa, 1975-85," Finance and Development, 1980, 17, pp. 32-6.

Tower, Edward "The geometry of community indifference curves," Weltwirtschaftliches Archiv, 1969, 115, pp. 680-700. 